\title{
Józef Bańka, Uczta cyfrowa uczestników kongresu zwołanego do Wieży Babel w sprawie cyfrowej nicości wiedzy, Wydawnictwo "Śląsk", Katowice 2017, 618 ss.
}

DOI: http://dx.doi.org/10.12775/RF.2017.043

Codziennie korzystamy z komputerów, laptopów, smartfonów, a w szczególności z Internetu; zwykle dostrzegamy tylko korzyści, które daje nam cywilizacja techniczna. Cieszymy się i jesteśmy dumni, że żyjemy w świecie, $\mathrm{w}$ którym są nam wszystkim dostępne takie wynalazki, o jakich królowie w średniowiecznej Europie nawet nie śmieli marzyć czy śnić. A jednak nie wszyscy są zgodni co do zalet tej „,cywilizacji komputerowej". Polski filozof Józef Bańka (ur. 1934) wydał niedawno książkę pt. Uczta cyfrowa uczestników kongresu zwołanego do Wieży Babel w sprawie cyfrowej nicości wiedzy, w której poddał krytyce współczesny świat zdominowany przez cyfryzację i komputeryzację. Chciałbym Państwu przedstawić główne idee tej pracy, choć oczywiście nie musimy się zgadzać z wszystkimi tezami Pana Profesora.

Jako wprowadzenie w tematykę książki może posłużyć cytat, który wprawdzie znajduje się na jej końcu, ale według mnie dobrze oddaje „klimat" całości rozważań J. Bańki:

Czyżby groził nam zmierzch cywilizacji uczuć? Jesteśmy świadkami zatrważającego znieczulenia na los ludzki, wobec przedstawionej tabeli cyfr nasze własne reakcje i doznania są bezsilne, jałowe, pozbawione ludzkiej wyobraźni. Staliśmy się w bałamutnym „cyfrowym języku migowym" ulicy niezdolni do współczucia, jeśli tylko należałoby nim obdarzyć miliony słabych odepchniętych. Dlatego z ekranu przemawia do nas tylko niedola pojedynczego nieszczęśnika. Co się stało z wrażliwością ludzką? Czy jest ona nieuniknionym łupem naszej cywilizacji cyfrowej? A wreszcie, czy pozbawieni tego ludzkiego skarbu możemy ufnie patrzeć w przyszłość, którą przesłania tabela cyfr? Oto istotne pytania, które stawia eutyfronika. Jest to problematyka, która powinna być drążona w głąb. Dokąd bowiem do tych procesów przykładamy tylko polityczne 
bądź ekonomiczne kryteria, jak dzieje się to często w publicystyce, nie posuwamy prognozy naszej przyszłości naprzód ${ }^{1}$.

Pojawia się tutaj pojęcie „eutyfronika”, które autor stworzył już przed kilkudziesięciu laty i oznacza ono - naukę (od gr. euthyphron „prostomyślny") - mającą na celu obronę ludzkiego życia i ludzkiego poczucia wspólnoty przed zimna, bezosobową cywilizacją. Eutyfronika zmierza do syntezy pierwiastka emocjonalnego thymos i racjonalnego phronesis $\mathrm{w}$ cywilizacji technicznej ${ }^{2}$. Tutaj z kolei znajdujemy pojęcie "prostomyślny", również stworzone przez J. Bańkę, które także domaga się wyjaśnienia. Otóż prostomyślność - to intuicyjnie niezawodny zmysł rozumienia życia, nie oparty na przesłankach naukowych. Intuicyjne rozumienie dobra i zła $\mathrm{w}$ etyce prostomyślności określa powinności spełnienia i budzi w człowieku gotowość do zachowania zgodnego $\mathrm{z}$ odczuwanymi wartościami ${ }^{3}$. $\mathrm{Z}$ kolei etyka prostomyślności - to system normatywny składający się ze wskazań „ciepłych”, apelujących do poręczenia moralnego człowieka prostomyślnego, który poszukuje zaspokojenia swych pragnień w możliwie prosty sposób ${ }^{4}$. Wartości „,ciepłe" to takie wartości, jak pomaganie cierpiącym, opieka nad słabszymi, życzliwość bezinteresowna, przyjaźń itp., których przeciwieństwem są „zimne” wskazania sfery cyfrowej, takie jak stanowczość, pewność siebie, zdyscyplinowanie, konsekwencja, wyrachowanie itd. ${ }^{5}$ Jeszcze jednym kluczowym pojęciem filozofii Pana Profesora, które pojawia się często w Uczcie... jest recentywizm (łac. recens - teraźniejszy, ang. recentivity - najświeższe dane) - to nowy kierunek filozoficzny, a dokładnie pogląd, który wyklucza możliwość, że jakiekolwiek doświadczenie, zdarzenie, dzieło jest $\mathrm{w}$ sensie cyfrowym dane i arytmetycznie powtarzalne, możliwe do ujęcia $\mathrm{w}$ ramach sieci i statystycznie przewidywalne, bo wszystko w sieci pojawia się jako pierworaźne, każdorazowo świeżo kreowane, tzn. „zrywające sieć”, z której problem próbuje się jak szczupak wyplątać 6 .

Jak widać, J. Bańka ma potrzebę tworzenia nowych słów w formułowaniu swoich poglądów. Z tego powodu jego książki (a napisał ich już prawie ...80 i wciąż pracuje nad kolejnymi) są trudne w odbiorze. Przyznam się, że choć pisałem doktorat z filozofii Pana Profesora, to jednak jego książki są dla mnie jednymi z trudniejszych filozoficznych tekstów.

1 J. Bańka, Uczta cyfrowa uczestników kongresu zwołanego do Wieży Babel w sprawie cyfrowej nicości wiedzy, Wyd. „Śląsk”, Katowice 2017, s. 580.

2 J. Bańka, Metafizyka wirtualna. Traktat o strukturach chwilowych, Wyd. Uniwersytetu Śląskiego, Katowice 2001, s. 286.

3 Ibidem, s. 291.

4 Ibidem, s. 286.

5 J. Bańka, Uczta cyfrowa..., s. 542.

6 Ibidem, s. 587. 
Jedynie teksty Kanta, Husserla i Heideggera są dla mnie trudniejsze lub prezentują podobny poziom trudności jak prace J. Bańki. Nie zamierzam przez to zniechęcać do ich lektury (wręcz przeciwnie, uważam, że są bardzo interesującym stanowiskiem $\mathrm{w}$ filozofii), niemniej jednak chcę uprzedzić potencjaln(ą)(ego) Czytelni(czkę)(ka), że na książki te trzeba poświęcić więcej czasu i uwagi niż na inne prace. Sama Uczta cyfrowa... ma 600 stron, więc nie jest to lektura "na jeden weekend”. Kto jednak ma zapał do „zagadek filozoficznych”, ten z pewnością w książkach Pana Profesora odnajdzie rzetelne rozważania ukryte „pod powłoką" trudnego języka.

Wróćmy do recenzowanej książki. Uczta cyfrowa... stanowi zapis z Kongresu Recentywistycznego zwołanego do Wieży Babel w obliczu stanu klęski cyfrowej nicości wiedzy. "Słowa wstępne” wygłaszają na nim dwie dziwne postacie (szczególnie ta druga z nich), mianowicie Anioł z Ognistym Mieczem - naczelny kolator scholarchatu zwanego Celestium oraz Mefistofeles - naczelny kolator scholarchatu zwanego Lucyferum. Poza tym cała praca stanowi obszerne mowy "aniołów” i „diabłów”, którzy dyskutują ze sobą o filozofii J. Bańki (występującego tu pod nazwa "Recencjusza") i co ciekawe - wszyscy oni zgadzają się ze sobą, co do dużej wartości poglądów twórcy recentywizmu, a tylko spierają się o różne ich aspekty. Pan Profesor powiedział mi (co też jest napisane na s. 23 dzieła), że książka ta jest pomyślana jako Boska komedia na XXI wiek. Nie od rzeczy będzie więc w tym miejscu zacytować słowa niezrównanego Dante Alighieri'ego:

„W życia wędrówce, na połowie czasu,

Straciwszy z oczu szlak niemylnej drogi,

W głębi ciemnego znalazłem się lasu"7.

I wytłumaczyć, że tym „ciemnym lasem” u naszego autora jest obecny świat cywilizacji technicznej.

Pracę niejako „otwiera" ciekawy, lecz mogący także budzić pewne kontrowersje tekst: Rodowód cyfrowej Wieży Babel według apokryfu Księgi Rodzaju. Czytamy tam, że Pan Bóg zasadził sad w Edenie i osadził tam Adama, a z jego żebra stworzył niewiastę - Ewę. W Edenie było Drzewo Cyfrowej Nicości Wiedzy Niesprzecznej, którego ludzie nie mogli dotykać, aby nie stali się Nativ - czyli ludźmi o cyfrowych dłoniach. Jednak wąż - demoniczny niszczyciel świata namówił Adama i Ewę do spożycia owocu z Drzewa Cyfrowej Nicości Wiedzy Niesprzecznej, w wyniku czego ludziom otworzyły się oczy i dowiedzieli się, że stanęli w obliczu klęski cyfrowej nicości wiedzy, że oboje prawdziwie są teraz „zero i jed-

7 D. Alighieri, Boska komedia, przeł. E. Porębowicz, Wyd. „Zielona Sowa”, Kraków 2004, s. 5. 
no". I w ten sposób człowiek stał się Nativ - zwierzęciem o cyfrowych dłoniach (pianthropus digitalis) ${ }^{8}$.

A teraz zobaczymy pokrótce, jak J. Bańka ukazuje eutyfronikę, etykę prostomyślności i recentywizm $\mathrm{w}$ analizowanej pracy.

Czytamy, że eutyfronika jest w jakimś sensie ideą psychoterapii, która za punkt wyjścia przyjmuje krytykę intelektualizmu etycznego?. Jest też "terapią humanistyczną", buntem skierowanym przeciwko dominacji martwego pola cyfrowej nicości wiedzy, jej cyfrowego rozformowania, przeciw bezwzględnej cyfryzacji „nadwyżki” sensu ludzkiego życia ${ }^{10}$. Eutyfronika Recencjusza posługuje się hasłem „powrotu do Natury"11.

Z kolei punktem wyjścia etyki prostomyślności jest diagnoza, wedle której człowiek poszukuje zaspokojenia swoich pragnień w sposób jak najprostszy, gdy tymczasem gubi się w martwym polu cyfrowej nicości wiedzy; gdy znajdzie się w tym polu, musi przyswoić sobie bardziej pośredni i skomplikowany sposób zachowania się ${ }^{12}$. Homo euthyphronicus (człowiek prostomyślny) - opiera się na prostocie i słuszności myśli ${ }^{13}$. Prostomyślność jako zmysł słusznego rozumienia życia, który nie opierając się nawet na przesłankach naukowych, jest intuicyjnie niezawodny, chroni w końcu „umysł mroczny” człowieka przed postawą analityczną ${ }^{14}$. Postawa sceptyczna, pogodna i po Sokratejsku ironiczna, tj. oparta na prostomyślności, wydaje się najmądrzejszym znanym od starożytności stosunkiem do życia, postawą najbardziej godną człowieka ${ }^{15}$.

Kardynalna teza recentywizmu głosi, że prawda jest przedmiotem obecnym w śladach cyfrowych wypowiedzi zaistniałych w czasie teraźniejszym; fałsz przedmiotem obecnym $\mathrm{w}$ śladach cyfrowych wypowiedzi zaistniałych w czasie przeszłym i przyszłym; oraz wartość - przedmiotem obecnym w śladach cyfrowych wypowiedzi ogólnych, w których czas nie występuje, a przeszłość i przyszłość urywają się w martwym polu cyfrowej nicości wiedzy ${ }^{16}$. Dyrektywa etyki może przyjąć brzmienie: „Żyj tak, aby upływ czasu był dla ciebie upływem teraźniejszości, a rozstrzygniesz swoją zagadkę punktu wyjścia - zobaczysz wtedy na próbę, jak się żyje wiecznie. Pamiętaj, że w cyfrowym upływie czasu ostatnia zanikająca cyfra jest także twoją teraźniejszością"17. Znajdujemy

8 Por. J. Bańka, Uczta cyfrowa..., s. 10-13.

Ibidem, s. 110.

Ibidem, s. 165.

Ibidem, s. 463.

Ibidem, s. 532.

Ibidem, s. 456.

Ibidem, s. 308.

Ibidem, s. 380.

Ibidem, s. 54.

Ibidem, s. 32. 
też tutaj jedno z najczęściej pojawiających się haseł w książkach Pana Profesora: „Życie człowieka jest ważne bezpośrednio teraz, a nie dopiero jako środek do osiągnięcia czegoś w przyszłości"18.

Przejdźmy z kolei do najistotniejszych treści pracy, czyli owej krytyki „cywilizacji komputerowej”, jak ją określiłem, chociaż sam J. Bańka tym pojęciem się nie posługuje, a zamiast tego mówi o zagrożeniach wynikających z powszechnej cyfryzacji.

Czytamy, że totalna cyfryzacja życia ludzkich społeczeństw uprzywilejowuje małe grupy społeczne, tzw. Kogitariat, pogrążając miliardy ludzi w ubóstwie i spychając je do roli cyfrowego proletariatu. Więc albo świat się zhumanizuje i wróci do etyki prostomyślności, albo cywilizacja ludzka zacznie się zwijać w kierunku końca ${ }^{19}$. Kryteria wyboru w sferze humanistycznej, a więc w sferze prostomyślności moralnej wskazuja, że człowiek jest najwyższą wartościa, że więc postęp w sferze cywilizacji cyfrowej nie może być celem samym dla siebie, słowem - nie może być przeciwstawny interesom zdrowia psychicznego społeczeństwa jako całości ani interesom zdrowia psychicznego człowieka jako jednostki $\mathrm{w}$ całokształcie jego indywidualnych aspiracji ${ }^{20}$. Cyfra bowiem zamienia „wartośćc na "łatwość", jako że w „bałamutnym cyfrowym języku migowym", przeznaczonym przez Wielki Kogitariat dla proletariatu ulicy, nie trzeba znać konstrukcji wielu maszyn, żeby się nimi móc posługiwać, eliminując prawie zupełnie użycie sił fizycznych i intelektualnych $^{21}$. Forsowanie cyfryzacji, bez jednocześnie rozsądnej humanizacji, może spowodować arytmię postępu, a więc swego rodzaju zapaść systemu wartości. To martwe pole oznaczałoby bowiem sytuację, w którejłatwo wprawdzie byłoby żyć, ale w której żyć nie byłoby warto!22

Nasz autor pisze, że komputer wymaga od człowieka większej uwagi i zaangażowania w paradoksalnej sytuacji „odwróconej zależności”: zamiast komputer być dla człowieka, to człowiek wkracza w martwe pole cyfrowej nicości wiedzy, jej cyfrowego rozformowania, kiedy ginie w chmurze ponikowej, tzn. istnieje nieprzerwanie w służbie komputera, tak iż być może należałoby mówić o miejscu człowieka w życiu komputera $^{23}$. Z kolei enigmatyczna okazuje się sytuacja człowieka w dostrzegalnej perspektywie nauki do 2100 roku, kiedy to mają mu towarzyszyć na co dzień: chłodne roboty na rogatkach ulic, autostrady przypominające trasy poduszkowców wodnych, idące obrotowo za słońcem wieżowce naśladujące $\mathrm{w}$ wielkich metropoliach fototropizm ciem, tabletki

\footnotetext{
18 Ibidem, s. 72.

19 Ibidem, s. 5.

20 Ibidem, s. 181.

21 Ibidem, s. 295.

22 Ibidem, s. 302.

23 Ibidem, s. 346.
} 
pamięci komputerowej, podawane kierowcom przez automaty na parkingach w miejscach, gdzie obecnie dyżurują bary firmy McDonalds. To wszystko! A jednak o wiele za mało! ${ }^{24}$ A jest tak dlatego, że busoli moralnej nie da się stworzyć w laboratorium: nie samą cyfrą człowiek żyje, potrzeba mu jeszcze - jak mówi poeta - wielkiej idei, „,czekania myśli życia, co przyjść do niego miała"25. Natomiast maszyna cyfrowa nie potrzebuje wszystkich walorów człowieka, a w szczególności jego emocji, które z tego powodu stają się zbyteczne. Wzrastający stopień cyfryzacji - określany eufemistycznie jako uwolnienie myśli - w bałamutnym „cyfrowym języku migowym" ulicy może doprowadzić do tego, że jednostka, aczkolwiek bezpieczna i syta, będzie kontrolowana we wszystkich rozwinięciach śladów cyfrowych miejsc dziesiętnych po przecinku, tj. we wszystkich sferach swojej życiowej działalności ${ }^{26}$.

Myślę, że omawianą książkę można porównać nie tylko z Boska komedia, lecz także, na co wskazuje jej tytuł, z najsłynniejsza, jak się zdaje, książką filozoficzna, a mianowicie - z Ucztą Platona. Różnią się one jednak tym, że Wielki Ateńczyk podejmuje w swej pracy zagadnienie miłości, podczas gdy polski filozof milczy na ten temat. W jednej z moich ostatnich książek, zarzuciłem właśnie Panu Profesorowi, że w swoich pracach o etyce prostomyślności - praktycznie nic nie pisze o miłości ${ }^{27}$. Trzeba jednak uczciwie powiedzieć, że właściwie wszyscy filozofowie tego tematu nie poruszaja a jedynym, o ile mi wiadomo, który napisał obszerną książkę poświęconą temu zagadnieniu był Max Scheler ${ }^{28}$. Natomiast wiele o miłości piszą psycholodzy ${ }^{29}$. Myślę, że to duża ułomność myśli filozoficznej, iż nie wypowiada się na ten temat. Miłość jest bowiem podstawową wartością w życiu człowieka; dzieci potrzebują jej, aby się prawidłowo rozwijały (a gdy nie są nią obdarzone - to przejawiają zachowania antyspołeczne), młodzi ludzie „z pasją” poszukują swojej "drugiej połówki", a osoby dorosłe i starsze też pragną być otoczone miłością. Wydaje mi się więc, że w swojej książce J. Bańka powinien temu zagadnieniu poświęcić trochę miejsca, abyśmy zobaczyli, co ma w tej kwestii do powiedzenia. Warto jednak odnotować, że naczelna dyrektywa etyki prostomyślności, która głosi: „Szanuj w drugim te wartości, którymi on jest ożywiony, i które przeżywa on jako wartości osobiste,

24 Ibidem, s. 376.

25 Ibidem, s. 401.

26 Ibidem, s. 405.

27 Zob. A. Skorupka, Gry i zabawy. Wittgenstein - Huizinga - Bańka, Wyd. „Progres", Sosnowiec 2017, s. 136.

28 Zob. M. Scheler, Istota i formy sympatii, przeł. A. Węgrzecki, Państwowe Wydawnictwo Naukowe, Warszawa 1980.

29 Por. np. E. Fromm, O sztuce miłości, przeł. A. Bogdański, Wyd. „Sagittarius”, Warszawa 1992. 
mające subiektywnie dla każdego największe znaczenie" ${ }^{\prime 30}$ - jest echem przykazania miłości braterskiej, które jest obecne w wielkich religiach.

Na koniec pozwolę sobie "zasiać” trochę wątpliwości co do istoty treści zaprezentowanego dzieła. Otóż można postawić pytanie, czy rzeczywiście „cywilizacja komputerowa”, czy sama cyfryzacja jest „tylko złem", czy też, być może, w przyszłości przyczyni się jedynie do podniesienia jakości życia ludzkości? Generalnie ta „rewolucja” w mediach elektronicznych zdarzyła się „na naszych oczach” i dlatego myślę, że za wcześnie jeszcze przewidywać wszystkie jej skutki. Ponadto wszytko, co nowe, budziło zawsze pewne obawy, np. gdy zaczynała się rewolucja przemysłowa, wielu martwiło się tym, że maszyny odbiorą ludziom pracę, gdy tymczasem proces industrializacji doprowadził do ogromnego wzbogacenia się ludzi. Podobnie może być z komputerami i Internetem; chociaż babcie i dziadkowie nieustannie narzekaja, że ich wnuki spędzają mnóstwo czasu na grach i surfowaniu po necie - z czasem, gdy dzieci dorosna, mogą preferować czy stworzyć znacznie bardziej bogate intelektualnie i kulturalnie formy „spędzania czasu przed monitorem”.

Wszyscy dobrze wiemy, że na świecie praktycznie każda rzecz ma swoje „dobre” i „złe” strony. Toteż książka J. Bańki, która akcentuje negatywne aspekty cyfryzacji, jest ważnym głosem w dyskusji nad przyszłością cywilizacji. Kiedy bowiem mnóstwo czasu spędzamy z komputerem, to wprawdzie „świetnie go rozumiemy”, ale często w ślad za tym - oduczamy się rozumienia emocji naszych bliźnich. Maszyny elektroniczne nie posługują się bowiem emocjami, a z tego powodu przebywanie tylko w ich "towarzystwie" niewątpliwie bardzo zubaża, żeby nie powiedzieć „wypacza” osobowość człowieka.

$Z$ recenzowaną książką na pewno warto się bliżej zapoznać, gdyż porusza istotne dla współczesnego świata problemy. Jak jednak już pisałem - nie jest to lektura "na dwa dni”, wymaga bowiem więcej czasu i namysłu nad jej wielowątkową treścią (a może nawet wymaga kilkakrotnego przeczytania). Niemniej jednak rzeczywisty „miłośnik mądrości” powinien po takie lektury sięgać z przyjemnością.

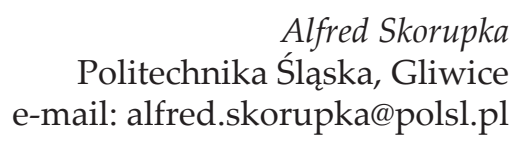

30 J. Bańka, Uczta cyfrowa..., s. 550. 